\title{
Peningkatan Kinerja melalui Perbaikan Iklim Organisasi dan Penguatan Etos Kerja
}

\author{
Panji Pramuditha1, Tjutju Yuniarsih², Hady Siti Hadijah $^{3}$ \\ 1,2,3 Universitas Pendidikan Indonesia \\ Jl. Dr. Setiabudi No.229, Isola, Kec. Sukasari, Kota Bandung, Jawa Barat 40154, Indonesia \\ e-mail: ${ }^{1}$ panji.pramuditha@upi.edu, ${ }^{2}$ yuniarsih@upi.edu, ${ }^{3}$ hady@upi.edu
}

\begin{abstract}
Informasi Artikel Diterima: 16-11-2020 Direvisi: 31-01-2020 Disetujui: 04-02-2021

Abstrak

Paradigma baik atau buruknya performa suatu perusahaan tidak terlepas dari kinerja sumber daya manusia sebagai motor penggeraknya. Terdapat beberapa faktor yang dapat mempengaruhi kinerja karyawan di suatu perusahaan seperti iklim organisasi yang menjadi ciri khas atau sebagai pembeda dari perusahaan lainnya dan etos kerja yang terdapat pada individu-individu karyawan. Pada penelitian ini akan membahas mengenai pengaruh iklim organisasi dan etos kerja terhadap kinerja karyawan baik secara parsial maupun secara simultan dengan jumlah sampel yang digunakan sebanyak 80 responden pada suatu perusahaan yang bergerak di bidang perkebunan pelat merah di Jawa Barat. Teknik analisis yang digunakan adalah analisis regresi berganda. Hasil penelitian menunjukkan bahwa iklim organisasi dan etos kerja berpengaruh positif signifikan terhadap kinerja karyawan baik secara parsial maupun simultan.
\end{abstract}

\section{Kata Kunci : Iklim Organisasi; Etos Kerja; Kinerja Karyawan}

\begin{abstract}
The paradigm of good or bad performance of a company cannot be separated from the performance of human resources as the driving force. There are several factors that can affect the performance of employees in a company, such as the organizational climate that is a characteristic or differentiator from other companies and the work ethic found in individual employees. This research will discuss about the influence of organizational climate and work ethic on employee performance either partially or simultaneously with the number of samples used as many as 85 respondents at a company engaged in state-owned plantations in West Java. The analysis technique used is multiple regression analysis. The results showed that organizational climate and work ethic had a siginificant positive effect on employee performance either partially or simultaneously.
\end{abstract}

\section{Keywords: Climate Company; Work Ethic; Employee Performance}

\section{Pendahuluan}

Dalam menghadapi persaingan, perusahaan diharuskan untuk memiliki SDM (sumber daya manusia) yang berkualitas demi tercapainya tujuantujuan perusahaan. Sumber daya manusia menjadi salah satu indikator keberhasilan pada perusahaan yang bergerak di semua sektor tak terkecuali pada perusahaan agroindustri milik pemerintah atau pelat merah yang dikenal dengan istilah BUMN (Badan Usaha Milik Negara). Badan usaha ini menyangkut dengan hajat hidup orang banyak dalam meningkatkan taraf hidup masyarakat. Demi tercapainya tujuan-tujuan badan usaha tersebut diperlukan suatu kinerja sumber daya manusia atau karyawan yang kompeten. Kinerja karyawan merupakan tujuan akhir dan merupakan cara bagi manajer untuk memastikan bahwa aktivitas pegawai dan output yang dihasilkan sinergi dengan tujuan organisasi atau perusahaan. Menurut Robbins dan Judge (2012) menjelaskan bahwa kinerja karyawan pada dasarnya adalah kemampuan karyawan dalam menyeluruh pekerjaan yang ditangani dan sikap positif yang ditunjukkan karyawan di tempat kerja. Kemampuan menyelesaikan pekerjaan artinya karyawan mampu menyelesaikan pekerjaan dengan baik (sesuai dengan standar yang telah ditetapkan perusahaan perkebunan tersebut), dan karyawan berperilaku positif yang ditunjukkan dari sikapnya untuk mentaati peraturan perusahaan, dan lainnya. Salah satu penilaian yang dapat mempengaruhi kinerja karyawan adalah iklim organisasi.

Iklim organisasi pada perusahaan perkebunan tersebut bersifat menekan, netral atau dapat pula bersifat mendukung, tergantung bagian mengaturnya, karena itu setiap organisasi selalu mempunyai iklim kerja yang unik. Organisasi 
cenderung menarik dan mempertahankan orangorang yang sesuai dengan iklimnya, sehingga dalam tingkatan tertentu polanya dapat langgeng. Menurut Luthans dalam Simamora (2011:34) menyebutkan bahwa iklim organisasi adalah lingkungan internal atau psikologi organisasi. Iklim organisasi mempengaruhi praktik dan kebijakan SDM yang diterima oleh anggota organisasi. Jika iklim organisasi bersifat konstruktif dan mendukung, maka kinerja karyawan menjadi lebih produktif serta tujuan-tujuan perusahaan dapat diraih.

Iklim organisasi dapat mempengarui dan atau dipengaruhi oleh etos kerja setiap individu-individu di dalamnya. Menurut Sinamo (2013) bahwa etos kerja profesional adalah seperangkat perilaku kerja positif dan bermutu tinggi yang berakar pada kesadaran yang jernih dan keyakinan yang kuat pada paradigma kerja yang holistik. Etos kerja sebagai pendorong sebuah perbuatan dan pernggairah dalam aktivitas, jika dalam konteks yang positif dapat meningkatkan produktivitas kerja dalam rangka pencapaian tujuan-tujuan perusahaan.

Penelitian ini akan menganalisis pengaruh iklim organisasi dan etos kerja terdapat kinerja karyawan pada sebuah perusahaan BUMN yang bergerak di sektor perkebunan area Jawa Barat.

Iklim organisasi sebagai suatu yang dapat diukur pada lingkungan kerja baik secara langsung maupun tidak langsung yang berpengaruh pada karyawan dan pekerjaannya di mana tempat mereka bekerja dengan asumsi akan berpengaruh pada motivasi dan perilaku karyawan (Litwin dan Stringer dalam Ratna Wijayanti, 2017). Sementara menurut Wirawan, dalam Mayang dan Umi (2019) iklim organisasi merupakan persepsi anggota organisasi dan mereka yang secara tetap berhubungan dengan organisasi mengenai apa yang ada atau terjadi di lingkungan internal organisasi secara rutin, yang mempengaruhi sikap dan perilaku oganisasi dan kinerja anggota organisasi yang kemudian menentukan kinerja organisasi. Iklim organisasi dapat diukur dengan :
a) Struktur
b) Tanggung jawab
c) Risiko
d) Imbalan dan sanksi
e) Kehangatan dan dukungan
f) Konflik

Menurut Sinamo (2013) bahwa etos kerja

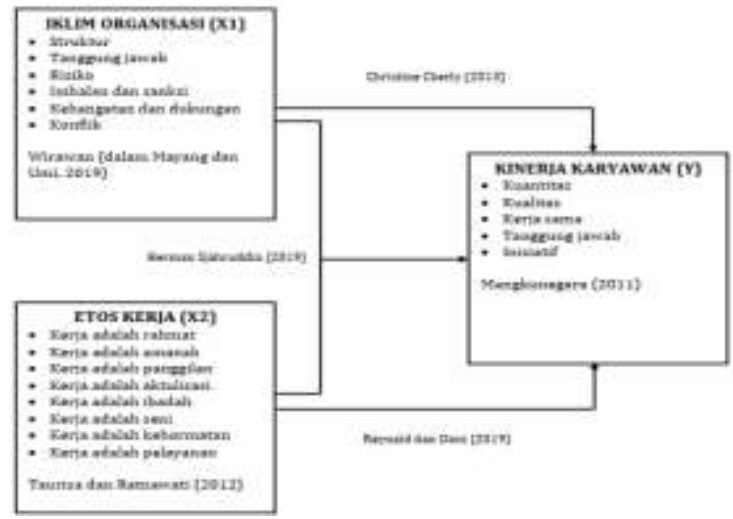

profesional adalah seperangkat perilaku kerja positif dan bermutu tinggi yang berakar pada kesadaran yang jernih dan keyakinan yang kuat pada paradigma kerja yang holistik. Etos kerja dapat diukur dengan :

a) Kerja adalah rahmat

b) Kerja adalah amanah

c) Kerja adalah panggilan

d) Kerja adalah aktulisasi

e) Kerja adalah ibadah

f) Kerja adalah seni

g) Kerja adalah kehormatan

h) Kerja adalah pelayanan

Menurut Taurisa dan Ratnawati (2012) Kinerja merupakan hasil kerja secara kualitas maupun kuantitas yang dicapai oleh seseorang dalam melaksanakan tugas yang diberikan kepadanya sesuai dengan standar atau kriteria yang telah ditetapkan. Kinerja menunjukkan tingkat keberhasilan karyawan dalam melaksanakan tugas dan tanggung jawabnya. Semakin tinggi kinerja karyawan, maka produktivitas organisasi secara keseluruhan akan meningkat. Sementara itu, Robbins dan Judge (2012) menjelaskan bahwa kinerja karyawan pada dasarnya adalah kemampuan karyawan dalam menyeluruh pekerjaan yang ditangani dan sikap positif serta ditunjukkan karyawan di tempat kerja. Kinerja karyawan dapat diukur dengan :

a) Kuantitas

b) Kualitas

c) Kerja sama

d) Tanggung jawab

e) Inisiatif

Iklim organisasi yang kondusif akan menunjang tercapainya tujuan-tujuan perusahaan melalui kinerja karyawannya. Sebaliknya, jika iklim organisasi tidak kondusif, maka dapat dipastikan tujuan-tujuan perusahaan tidak dapat tercapai dikarenakan sebagai akibat dari kinerja karyawan yang tidak maksimal. Hal ini dapat dibuktikan pada hasil penelitian Christine Cherly (2013) yang menunjukkan bahwa iklim organisasi memiliki pengaruh positif linier terhadap kinerja karyawan. Sehingga dapat disimpulkan semakin baik iklim 
organisasi, maka semakin baik pula kinerja karyawan.

Etos kerja pada karyawan dapat menciptakan motivasi untuk bekerja lebih produktif dan lebih baik lagi sehingga kinerja karyawan menjadi meningkat. Hal ini dapat dibuktikan pada penelitian Reynald dan Doni (2019) yang menunjukkan bahwa etos kerja memiliki pengaruh positif yang signifikan terhadap kinerja karyawan.

Kinerja karyawan dapat dibentuk oleh iklim organisasi yang kondusif dan etos kerja karyawan yang baik dapat dibuktikan pada penelitian Herman Sjahruddin (2019) yang menunjukkan bahwa iklim organisasi dan etos kerja memiliki pengaruh yang signifikan terhadap karyawan.

\section{Gambar 1. Paradigma Penelitian}

\section{Metode Penelitian}

Objek penelitian yaitu karyawan kantor pada perusahaan perkebunan pelat merah di Jawa Barat, dengan jumlah sampel sebanyak 80 karyawan. Penelitian ini menggunakan metode penelitian kuantitatif dengan analisis deskriptif dan verifikatif. Analisis deskriptif digunakan untuk mengetahui deskripsi dari masing-masing variabel, sementara analisis verifikatif untuk mengetahui apakah terjadi hubungan antara variabel independen terhadap variabel dependen dengan pendekatan uji regresi berganda. Sebelum uji verifikatif dilakukan, maka akan diuji terlebih dahulu uji instrumen (validitas dan reliabilitas) serta uji asumsi klasik (normalitas, multikolinearitas, dan heteroskedastisitas).

\section{Hasil dan Pembahasan \\ Analisis Deskripif}

Berikut ini adalah hasil rekapitulasi tanggapan responden mengenai Iklim Organisasi, Etos Kerja, dan Kinerja Karyawan yang disajikan dalam bentuk garis kontinum, yaitu sebagai berikut:

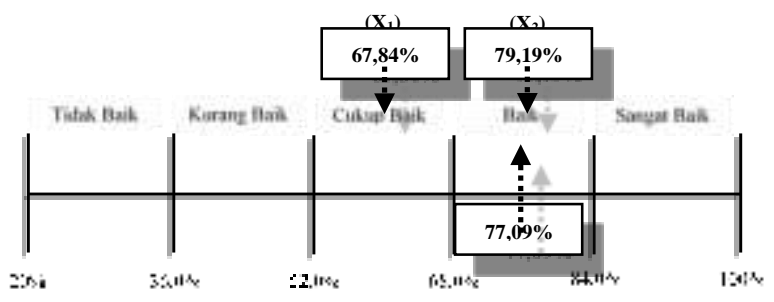

Gambar 2. Garis Kontinum Iklim Organisasi $\left(\mathrm{X}_{1}\right)$, Etos Kerja $\left(\mathrm{X}_{2}\right)$, dan Kinerja Karyawan

(Y)

Berdasarkan hasil rekapitulasi secara keseluruhan pada garis kontinum di atas, maka dapat diketahui pada variabel Iklim Organisasi $\left(\mathrm{X}_{1}\right)$ ada pada kategori cukup baik dengan perolehan skor persentase sebanyak 67,84\%. Pada variabel Etos Kerja $\left(\mathrm{X}_{2}\right)$ ada pada kategori baik dengan perolehan skor persentase sebanyak $79,19 \%$. Sementara pada variabel Kinerja Karyawan ada pada kategori baik dengan perolehan skor persentase sebanyak 77,09\%.

\section{Analisis Verifikatif}

\section{Uji Instrumen}

- Uji Validitas

Berdasarkan hasil pengolahan data bahwa semua butir pernyataan pada variabel iklim organisasi, etos kerja, dan kinerja karyawan memiliki nilai di >0,30 dan siginifikasinya $<0,05$ sehingga dapat disimpulkan bahwa semua butir pernyataan dalam penelitian ini valid dan layak untuk digunakan.

\section{- Uji Reliabilitas}

Berdasarkan hasil pengolahan data bahwa semua butir pernyataan pada variabel iklim organisasi, etos kerja, dan kinerja karyawan memiliki nilai cronbach alpha >0,60 sehingga dapat disimpulkan bahwa semua butir pernyataan dapat diandalkan dan memenuhi standar.

\section{Uji Asumsi Klasik}

- Uji Normalitas

Berdasarkan tabel output uji kolmogorov smirnov, diperoleh nilai probabilitas (Asymp. Sig. (2-tailed)) sebesar 0,904. Nilai signifikansi (p-value) tersebut lebih besar dari 0,05, sehingga dapat disimpulkan bahwa data model regresi sudah berdistribusi normal.

Tabel 1. Uji Normalitas

One-Sample Kolmogorov-Smirnov Test

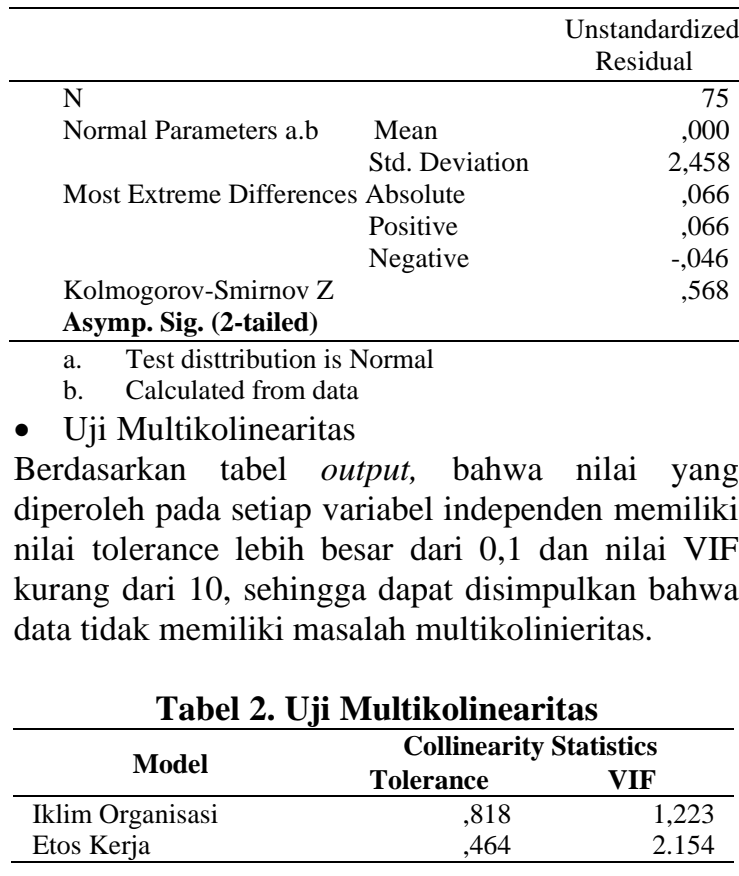

- Uji Heteroskedastisitas 
Berdasarkan hasil pengolahan data bahwa hasil scatterplot menyebar di atas dan di bawah nilai angka 0 dalam artian tidak mengumpul pada sati sisi saja serta tidak membentuk pola gelombang sehingga pada penelitian ini tidak terjadi heteroskedastisitas.

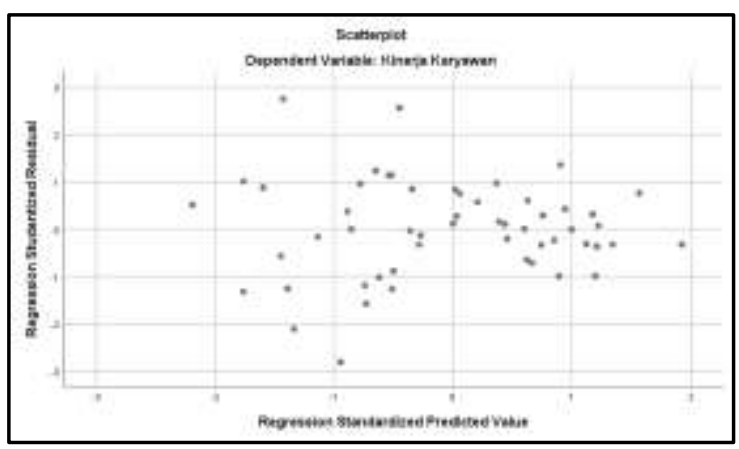

Gambar 3. Uji Heteroskedastisitas

\section{Uji Regresi Berganda}

Berikut ini adalah hasil uji koefisien korelasi yang ditampilkan pada tabel di bawah ini :

Tabel 3. Koefisien Korelasi Parsial $X_{1}$

\begin{tabular}{|c|c|c|c|}
\hline & & $\begin{array}{c}\text { Iklim } \\
\text { Organisasi }\end{array}$ & $\begin{array}{c}\text { Kinerja } \\
\text { karyawan }\end{array}$ \\
\hline \multirow{3}{*}{$\begin{array}{l}\text { Iklim } \\
\text { Organisasi }\end{array}$} & $\begin{array}{l}\text { Pearson } \\
\text { Correlation }\end{array}$ & 1 & ,614 \\
\hline & Sig. (2-tailed) & & ,000 \\
\hline & $\mathrm{N}$ & 80 & 80 \\
\hline \multirow{3}{*}{$\begin{array}{l}\text { Kinerja } \\
\text { karyawan }\end{array}$} & $\begin{array}{l}\text { Pearson } \\
\text { Correlation }\end{array}$ & ,614 & 1 \\
\hline & Sig. (2-tailed) & ,000 & \\
\hline & $\mathrm{N}$ & 80 & 80 \\
\hline
\end{tabular}

Berdasarkan tabel 3 dapat dilihat nilai korelasi antara iklim organisasi dengan kinerja karyawan adalah sebesar 0,614 dan berada pada interval 0,61-0,80 termasuk kategori cukup tinggi dengan arah positif. Sehingga dapat diketahui bahwa terdapat hubungan positif yang cukup tinggi antara iklim organisasi dengan kinerja karyawan, di mana semakin baik iklim organisasi maka, akan diikuti semakin baiknya kinerja karyawan pada kantor perusahaan perkebunan pelat merah tersebut.

Tabel 4. Koefisien Korelasi Parsial $\mathrm{X}_{2}$

\begin{tabular}{|c|c|c|c|}
\hline & & Etos Kerja & $\begin{array}{c}\text { Kinerja } \\
\text { karyawan }\end{array}$ \\
\hline \multirow{3}{*}{$\begin{array}{l}\text { Etos } \\
\text { Kerja }\end{array}$} & $\begin{array}{l}\text { Pearson } \\
\text { Correlation }\end{array}$ & 1 & ,718 \\
\hline & Sig. (2-tailed) & & ,000 \\
\hline & $\mathrm{N}$ & 80 & 80 \\
\hline \multirow{3}{*}{$\begin{array}{l}\text { Kinerja } \\
\text { karyawan }\end{array}$} & $\begin{array}{l}\text { Pearson } \\
\text { Correlation }\end{array}$ & ,718 & 1 \\
\hline & Sig. (2-tailed) &, 000 & \\
\hline & $\mathrm{N}$ & 80 & 80 \\
\hline
\end{tabular}

Berdasarkan tabel 4 di atas, dapat dilihat nilai korelasi antara etos kerja dengan kinerja karyawan adalah sebesar 0,718 dan berada pada interval 0,610,80 termasuk kategori cukup tinggi dengan arah positif. Sehingga dapat diketahui bahwa terdapat hubungan positif yang cukup tinggi antara etos kerja dengan kinerja karyawan, di mana semakin baik etos kerja, maka akan diikuti semakin baiknya kinerja karyawan pada kantor perusahaan perkebunan pelat merah tersebut.

Tabel 5. Koefisien Determinasi (R-Square) Model Summary

\begin{tabular}{llrrr}
\hline Model & $\mathrm{R}$ & R Square & $\begin{array}{c}\text { Adjusted R } \\
\text { Square }\end{array}$ & $\begin{array}{c}\text { Std Error Of } \\
\text { the Estimate }\end{array}$ \\
\hline 1 & 814 &, 662 &, 648 & 2,509007
\end{tabular}

Berdasarkan tabel 5 di atas, menunjukkan bahwa kinerja karyawan pada kantor perusahaan perkebunan pelat merah tersebut mampu dipengaruhi oleh iklim organisasi dan etos kerja mencapai $66,20 \%$, sedangkan sisanya sebesar $33,8 \%$ merupakan pengaruh atau kontribusi dari variabel lain yang tidak diteliti diluar penelitian.

Tabel 6. Koefisien Determinasi Variabel

Independen Terhadap Variabel Depeden

\begin{tabular}{lrr}
\hline Model & $\begin{array}{c}\text { Standarized } \\
\text { Coefficient } \\
\text { Beta }\end{array}$ & \multicolumn{2}{c}{$\begin{array}{c}\text { Correlations } \\
\text { Zero-Order }\end{array}$} \\
\hline Iklim &, 362 &, 614 \\
Organisasi & &, 718 \\
Etos Kerja &, 247 &, 70 \\
\hline
\end{tabular}

Berdasarkan tabel 6, dapat diketahui :

a) $\mathrm{X}_{1}: 0,362 \times 0,614=0,222$ atau $22,2 \%$

b) $\mathrm{X}_{2}: 0,247 \times 0,718=0,178$ atau $17,8 \%$

Dari hasil perhitungan di atas, dapat diketahui bahwa dari total kontribusi sebesar $66,2 \%$, variabel yang paling berpengaruh terhadap Kinerja Karyawan adalah variabel Iklim Organisasi $\left(\mathrm{X}_{1}\right)$ sebesar $22,2 \%$, sementara variabel Etos Kerja $\left(\mathrm{X}_{2}\right)$ sebesar $17,8 \%$ pada kantor perusahaan perkebunan pelat merah tersebut.

Tabel 7. Uji t

\begin{tabular}{|c|c|c|c|c|c|}
\hline \multirow{2}{*}{ Model } & \multicolumn{2}{|c|}{$\begin{array}{l}\text { Standarized } \\
\text { Coefficient }\end{array}$} & \multirow{2}{*}{$\begin{array}{c}\text { Standarized } \\
\text { Coefficient } \\
\text { Beta }\end{array}$} & \multirow{2}{*}{$\mathrm{t}$} & \multirow{2}{*}{ Sig. } \\
\hline & B & $\begin{array}{l}\text { Std. } \\
\text { Error }\end{array}$ & & & \\
\hline (Constant) & $2,16^{-}$ & 3,297 & &,- 655 &, 515 \\
\hline $\begin{array}{l}\text { Iklim } \\
\text { Organisasi }\end{array}$ & ,382 & ,081 & ,362 & 4,745 &, 000 \\
\hline Etos Kerja & , 177 & ,063 & ,247 & 2,801 & ,006 \\
\hline
\end{tabular}

$\mathrm{H} 0: \beta 1=0$

Iklim organisasi tidak berpengaruh signifikan terhadap kinerja karyawan pada kantor 
perusahaan perkebunan pelat merah.

$\mathrm{H} 1: \beta 1 \neq 0 \quad$ Iklim organisasi berpengaruh signifikan terhadap kinerja karyawan pada kantor perusahaan perkebunan pelat merah.

Dengan tingkat signifikan $(\alpha)$ sebesar $5 \%$, df $=79$, sehingga diperoleh $t_{\text {tabel }}$ untuk uji dua pihak sebesar $-1,994$ dan 1,994 .

Berdasarkan tabel 7 di atas, nilai $t_{\text {hitung }}$ lebih besar dari $t_{\text {tabel }}$ yaitu 4,745 > 1,994 dan sigifikansi $0,000<0,05$ artinya secara parsial Iklim Organisasi berpengaruh signifikan terhadap Kinerja Karyawan pada kantor perusahaan perkebunan pelat merah.

$\mathrm{H} 0: \beta 1=0 \quad$ Etos kerja tidak berpengaruh signifikan terhadap kinerja karyawan pada kantor perusahaan perkebunan pelat merah.

H1: $\beta 1 \neq 0 \quad$ Etos kerja berpengaruh signifikan terhadap kinerja karyawan pada kantor perusahaan perkebunan pelat merah.

Berdasarkan tabel $7 \mathrm{di}$ atas, nilai $\mathrm{t}_{\text {hitung }}$ lebih besar dari tabel yaitu 2,801 > 1,994 dan sigifikansi $0,006<0,05$ artinya secara parsial Etos Kerja berpengaruh signifikan terhadap Kinerja Karyawan pada kantor perusahaan perkebunan pelat merah.

Tabel 8. Uji f

\begin{tabular}{|c|c|c|c|c|c|}
\hline Model & $\begin{array}{l}\text { Sum } \\
\text { of } \\
\text { Squa } \\
\text { res }\end{array}$ & df & $\begin{array}{l}\text { Mean } \\
\text { Square }\end{array}$ & $\mathrm{F}$ & Sig. \\
\hline Regression & $\begin{array}{r}1344 \\
.674\end{array}$ & 2 & 672.337 & 97.820 & $.000^{\mathrm{b}}$ \\
\hline Residual & $\begin{array}{r}556 . \\
728\end{array}$ & 79 & 6.873 & & \\
\hline Total & $\begin{array}{r}1901 \\
.402 \\
\end{array}$ & 80 & & & \\
\hline
\end{tabular}

Berdasarkan tabel 8 di atas, hasil uji hipotesis secara simultan $(F)$ ditunjukkan oleh nilai $F_{\text {hitung }}$ sebesar 97,820 dengan nilai Sig. sebesar 0,000; maka $F_{\text {hitung }}>F_{\text {tabel }}(97,820>2,734)$ yang dapat disimpulkan bawah Iklim Organisasi dan Etos Kerja secara simultan berpengaruh signifikan terhadap Kinerja Karyawan pada kantor perusahaan perkebunan pelat merah tersebut.

\section{Kesimpulan}

Berdasarkan hasil penelitian dari pembahasan mengenai Iklim Organisasi dan Etos Kerja terhadap Kinerja Karyawan pada kantor perusahaan perkebunan pelat merah tersebut, maka dapat disimpulkan dari analisis deskriptif mengenai Iklim Organisasi pada karyawan di kantor perusahaan perkebunan pelat merah berada pada kategori cukup baik. Dari analisis deskriptif mengenai Etos Kerja pada karyawan di kantor perusahaan perkebunan pelat merah berada pada kategori baik. Dari analisis deskriptif mengenai Kinerja Karyawan pada karyawan di kantor perusahaan perkebunan pelat merah berada pada kategori baik. Dari hasil analis verifikatif bahwa Iklim Organisasi dan Etos Kerja berpengaruh positif siginifikan pada Kinerja Karyawan pada kantor perusahaan perkebunan perlat merah baik secara parsial maupun secara simultan.

Maka rekomendasi yang dapat sebaiknya dilakukan Mengenai Iklim Organisasi, sebaiknya mempertahankannya yang mencakup kemampuan atau sikap karyawan untuk membangun kordinasi antara sesama bawahan di dalam perusahaan yang dinyatakan sudah cukup kondusif. Mengenai Etos Kerja, sebaiknya untuk tidak membawa masalahmasalah pribadi ke dalam tugas atau tanggung jawab pekerjaan. Mengenai Kinerja Karyawan, sebaiknya mempertahankan kinerjanya agar tujuan-tujuan dari perusahaan dapat tercapai. Penggunaan model penelitian dapat dikombinasikan dengan penelitian lain yang juga berhubungan dengan Kinerja Karyawan, mulai dari sistem penghargaan karyawan, kepuasan karyawan, perilaku karyawan, gaya kepemimpinan, motivasi karyawan, pengembangan karyawan ataupun lingkungan kerja yang secara langsung mempengaruhi kinerja karyawan.

\section{Referensi}

Christine Cherly Karundeng. 2013. Pengaruh Iklim Organisasi Terhadap Kinerja Karyawan Pada PT. Taspen (Persero) Cabang Manado. Jurnal Unsrat Vol. 2 No. 3.

Evan Karno P dan Ayu Desi 1. 2016. Pengaruh Iklim Organisai \& Kualitas Kehidupan Kerja terhadap Kinerja Pegawai Dinas Sosial Provinsi BaIi. E-JurnaI Manajemen Unud. VoI 5, No. 12, 2016: 7785-7809 ISSN 23028912.

Hadiansyah dan Yanwar. 2015. Pengaruh Etos Kerja Terhadap Kinerja Karyawan PT. AE. Jurnal Al-Azhar Indonesia Seri Humaniora, Vol. 3 No. 2, September 2015.

Henry Simamora. 2011. Manajemen Sumber Daya Manusia, STIE YKPN. Yogyakarta.

Herman Sjahruddin. 2019. Pengaruh Etos Kerja dan Iklim Organisasi Terhadap Kinerja Karyawan. Organisasi dan Manajemen Issue 1 (Agustus, 2019).

Luthans, F. 2006. Perilaku Organisasi. Yogyakarta: Andi, Diterjemahkan oleh Vivian A Yuwono.

Litwin \& Stringer's, 2011, Motivation and organizational climate. Boston: Harvard University Press.

Moch Irsan Firmansyah dan Raeny Dwi Santy ,2011.Pengaruh IklIm Organisasi dan Karakteristik Pekerjaan terhadap Kepuasan Kerja Pegawal di Iingkunan Pemerintah 
Daerah Kabupaten Sukabuml. Majalah IImiah Unikom. Vol 6 No. 2.

Prima Aprilyani Rambe. 2018 Pengaruh karakteristik pekerjaan, iklim organisasi dan kepuasan kerja terhadap kinerja karyawan Jurnal Dimensi, Vol. 7, NO. 2 : 368-392 JULI 2018 ISSN: 2085-9996

Ratna, Wijayanti. (2017). Pengaruh Iklim Organisasi, Etos Kerja Dan Disiplin Kerja Terhadap Efektifitas Kinerja Organisasi Di Fakultas Ekonomi Unsiq Wonosobo. Jurnal. Fakultas Ekonomi Universitas Sains Al Qur'an (UNSIQ) Wonosobo. Jurnal PPKM II.

Reynald dan Doni. 2019. Pengaruh Pendidikan, Pengalaman Kerja, dan Etos Kerja Terhadap Kinerja Pehgawai di KPN Batur. OCS AKBPSTIE.

Robbins, P.Stephen dan Timothy A. Judge. 2012. Perilaku Organisasi. Salemba Empat. Jakarta.
Sinamo, Jansen H. 2003. Etos Kerja Profesional di Era Digital Global, Ed 1. Jakarta: Institut Darma Mahardika.

Taurisa dan Ratnawati. 2012. Analisis Pengaruh Budaya Organisasi dan Kepuasan Kerja Teradap Komitmen Organisasional Dalam Meningkatkan Kinerja Karyawan (Studi pada PT. SIdo Muncul Kaligawe Semarang). Jurnal Bisnis dan Ekonomi (JBE) September 2020 Vol. 19 No. 2.

Timbuleng, Stela., Sumarauw, Jacky. 2015. Etos Kerja, Disiplin Krja, dan Komitmen Organisasi Pengaruhnya Terhadap Kinerja Karyawan Pada PT. Hasjrat Abadi Cabang Manado. Jurnal EMBA Vol. 3 No. 2 Juni 2015.

Wirawan. 2007. Budaya dan Iklim Organisai, Teori apIikasi dan PeneIitian. Jakarta: Selemba Empat. 